\title{
PENGOLAHAN MINYAK KELAPA MURNI (VCO) DENGAN METODE FERMENTASI MENGGUNAKAN RAGI TAPE MERK NKL
}

\author{
Muharun, S.TP ${ }^{(1)}$ dan Mulono Apriyantono ${ }^{(2)}$ \\ ${ }^{(1)}$ Alumni Teknologi Pangan Faperta UNISI \\ ${ }^{(2)}$ Dosen Teknologi Pangan Faperta UNISI
}

\begin{abstract}
Abstrak
Penelitian ini bertujuan untuk mengetahui persentase starter ragi tape yang tepat pada pengolahan VCO. Dari hasil penelitian pengolahan minyak kelapa murni (Virgin Coconut Oil) terhadap parameter yang diamati dapat diambil kesimpulan bahwa (1) Persentase ragi tape memberikan pengaruh yang sangat nyata terhadap rendemen hasil, kadar air, asam lemak bebas/FFA, organoleptik aroma, dan organoleptik warna, (2) semakin banyak penambahan ragi tape pada pengolahan minyak kelapa murni maka kualitas mutu minyak kelapa yan dihasilkan semakin tidak bagus tapi sebaliknya rendemen hasil meningkat, dan (3) Untuk kualitas yang terbaik pada minyak kelapa murni dengan penambahan stater ragi tape $\mathrm{A}_{1}(10 \%)$ yaitu dengan kadar air $\mathrm{A}_{1}(10 \%)=0,11 \%$, asam lemak bebas $\mathrm{A}_{2}(20 \%)=0,02 \%$, rendemen hasil $\mathrm{A}_{2}(20 \%)=23,88 \%$, organoleptik aroma $\mathrm{A}_{2}(20 \%)=3,00$, dan organoleptik warna $\mathrm{A}_{2}(20 \%)=3,00 \%$.
\end{abstract}

Kata Kunci : VCO, starter, ragi tape

\section{PENDAHULUAN}

Salah satu produk olahan kelapa yang banyak dibutuhkan masyarakat adalah minyak kelapa, dimana minyak kelapa mensuplai kurang lebih $10 \%$ dari total kebutuhan minyak dan lemak yang masuk ke pasar dunia (Hani Putranto, 1990). Permintaan minyak kelapa sedikit lebih tinggi dibandingkan dengan minyak dan lemak lain karena memiliki ciri khas dan kelebihan yang membuatnya cocok untuk bahan baku industri pangan khususnya dan kimia pada umumnya. Produksi minyak kelapa selalu meningkat sejalan dengan kenaikan kebutuhan minyak kelapa oleh masyarakat (Hui, 1996).

Menurut Onsaard et al (2005), bahwa pembuatan minyak cara basah dibagi dalam 3 (tiga) tahap berturut-turut yaitu pembuatan santan, pemisahan krim dan skim, dan pemecahan krim santan agar terpisah. Proses pengolahan minyak kelapa cara basah tanpa pemanasan dapat dilakukan dengan berbagai metode antara lain, metode fermentasi, enzimatis, pengasaman dan pancingan. Selain dari itu pemecahan krim dan santan dapat pula menggunakan ragi tape sebagai starter.

Salah satu hal yang paling sederhana adalah dengan mengolah kelapa menjadi VCO dengan menggunakan starter ragi tape. Berdasarkan hal tersebut, penulis tertarik untuk meneliti "Pengolahan Minyak Kelapa Murni (Virgin Coconut Oil) dengan Metode Fermentasi Menggunakan Starter Ragi Tape”.

Saat ini telah berkembang pengolahan VCO tanpa pemanasan dengan menggunakan minyak pancing sebagai starter. Dengan cara ini harus disediakan dahulu minyak pancing. Petani yang baru pertama kali mengolah 
VCO biasanya sulit memperoleh minyak pancing. Oleh karena itu, perlu dicari cara lain yang lebih mudah untuk memecahkan emulsi santan/krim melalui proses fermentasi tanpa menggunakan minyak pancing. Salah satu alternatif lain yang mudah bagi petani yaitu dengan menggunakan penambahan ragi tape sebagai starter untuk proses pemecahan emulsi santan/krim sehingga mendapatkan VCO yang diinginkan.

\section{Tujuan dan Manfaat Penelitian}

Penelitian ini bertujuan untuk mengetahui persentase starter ragi tape yang tepat pada pengolahan VCO.

Sedangkan manfaat dari penelitian ini adalah :

1. Memberikan alternatif pada masyarakat untuk mengolah kelapa menjadi suatu produk yang bermanfaat dan bernilai ekonomis tinggi dengan mengubah cara pengolahan biasa dengan menggunakan cara fermentasi dengan menggunakan starter ragi tape.

2. Memberi pengetahuan kepada masyarakat bahwa VCO banyak manfaatnya.

3. Memberikan pengetahuan kepada masyarakat bahwa ragi tape bisa dijadikan bahan alternatif dalam proses pengolahan VCO.

\section{Bahan}

Bahan-bahan yang digunakan dalam melakukan penelitian ini adalah : Buah kelapa tua layak petik (metal) yang diambil dari kebun petani Kabupaten Indragiri Hilir; ragi tape padat yang dibeli di pasar tradisional Tembilahan; $\mathrm{NaOH}$; asam asetat glasial; alkohol; fenolptalin; serta bahan pembantu lainnya.

\section{Alat}

Peralatan yang digunakan dalam penelitian ini adalah : parutan kelapa; pengepres santan; loyang plastik; wadah plastik transparan; corong plastik; wadah pengemas; pipet; labu ukur; oven; baskom; saringan plastik; kain saring; kertas saring; dan selang air.

\section{Rancangan Percobaan}

Rancangan percobaan penelitian adalah dengan menggunakan Rancangan Acak Lengkap (RAL) dengan tiga perlakuan starter ragi tape, yaitu :

$\mathrm{A} 1=10 \%$ starter ragi tape terhadap krim

$\mathrm{A} 2=20 \%$ starter ragi tape terhadap krim

$\mathrm{A} 3=30 \%$ starter ragi tape terhadap krim

Adapun pada pengujian pengolahan minyak kelapa murni dengan mengunakan starter ragi tape ialah dengan tiga kali ulangan sehingga ada 9 satuan percobaan.

\section{Persiapan Bahan Baku}

Buah kelapa yang akan diolah menjadi VCO adalah buah kelapa yang tua, yakni berumur 11-12 bulan. Ciri-ciri kelapa yang sudah tua ditandai oleh sabut kelapa berwarna kecoklatan (tampak kering), tempurung kelapa berwarna cokelat kehitaman dan lubang tempat tumbuh calon tanaman tertutup rapat. Buah kelapa tua akan menghasilkan randemen minyak yang tinggi.

\section{Pembuatan Santan}

Pembuatan santan merupakan salah satu tahapan dalam pembuatan minyak kelapa murni cara basah. Santan yang baik diperoleh dari buah kelapa yang secara fisiologis yaitu keadaan baik dan tua. Kelapa yang tua biasanya berumur \pm 12 bulan yang secara fisik 
ditandai dengan sabut kering dan berwarna coklat tua, tempurung berwarna coklat kehitaman dan lubang tempat pertumbuhan tunas tampak padat dan kompak. Santan kelapa berturutturut mengandung $20-35 \%$ minyak, 55 $-75 \%$ air dan $5-10 \%$ padatan bukan minyak (Tansakul dan Chaisawang, 2005).

Buah kelapa tua dikupas kemudian dibelah dan dagingnya dikeluarkan dari tempurung. Daging buah kelapa diparut dengan menggunakan mesin. Hancuran daging buah lalu dipres dengan mesin pres atau secara manual kemudian disaring sehingga diperoleh santan.

Santan yang diperoleh dituangkan pada ember plastik transparan, kemudian didiamkan selama 2 jam. Selama pendiaman, santan akan terbagi menjadi tiga lapisan, yaitu lapisan atas berupa krim adalah emulsi dengan kadar minyak relatif tinggi, lapisan tengah berbentuk skim (kaya protein) dan lapisan bawah (endapan) adalah padatan tidak larut dalam air.

\section{Pembuatan Starter Ragi Tape}

Pengolahan minyak kelapa murni (Virgin Coconut Oil) menggunakan ragi tape diawali dengan membuat cairan starter ragi tape. Caranya adalah, ambil skim kelapa $450 \mathrm{ml}$ dicampurkan dengan air kelapa $50 \mathrm{ml}$, kemudian ditambahkan ragi tape $2 \mathrm{~g}$, diaduk sampai homogen.
Setelah diaduk didiamkan (difermentasi) pada suhu ruang selama 12 jam.

\section{Pemecahan Krim Santan}

Krim yang diperoleh dibagi tiga bagian, kemudian campur dengan starter ragi tape masing-masing 10\%, 20\% dan $30 \%$. Campuran diaduk homogen kemudian dituang pada wadah transparan dan didiamkan selama $8-10$ jam. Selama proses pendiaman, campuran akan terpisah menjadi tiga lapisan, yaitu minyak (lapisan atas), blondo (lapisan tengah), dan air (lapisan bawah).

\section{Pengambilan/Pemanenan Minyak}

Minyak yang diperoleh dari pemecahan krim santan dipanen dengan cara menggunakan selang air. Minyak yang tidak dapat diambil menggunakan selang maka digunakan kain saring. Hasil dari pemecahan krim santan adalah minyak kelapa murni (Virgin Coconot Oil). Selanjutnya VCO dianalisa, ditutup rapat, disegel dan dikemas dengan baik.

\section{HASIL DAN PEMBAHASAN}

\section{Kadar Air}

Penambahan persentasi stater ragi tape pada pengolahan minyak kelapa murni dengan jumlah yang bervariasi berturut-turut $10 \%, 20 \%$ dan $30 \%$ ternyata berpengaruh nyata terhadap kadar air pada minyak kelapa murni yang diperoleh, seperti disajikan pada tabel 4.

Tabel 4. Kadar air pengolahan minyak kelapa penambahan starter ragi tape

\begin{tabular}{|l|l|}
\hline Perlakuan & Kadar Air Minyak Kelapa Murni (\%) \\
\hline $\mathrm{A}_{3}$ & $0.3200 \mathrm{~A}$ \\
$\mathrm{~A}_{2}$ & $0.2233 \mathrm{~B}$ \\
$\mathrm{~A}_{1}$ & $0.1133 \mathrm{C}$ \\
\hline
\end{tabular}

Keterangan : Angka-angka pada jalur yang sama diikuti oleh huruf kecil yang sama menunjukkan berbeda nyata menurut Uji Lanjut DMRT pada taraf 5\%. 
Dari tabel diatas kadar air terlihat bahwa $\mathrm{A}_{1}(10 \%)=05 \%, \mathrm{~A}_{2}(20 \%)=$ $0,1 \%$, dan $A_{3}(30 \%)=0,14 \%$. Semakin tinggi persentase starter ragi tape yang ditambahkan maka kadar air semakin tinggi. Hal ini disebabkan semakin tinggi starter ragi tape berarti juga semakin menurunkan $\mathrm{pH}$ sehingga mengakibatkan emulsifier protein yang mengikat lemak pada santan akan lebih banyak yang terkeagulasi sehingga banyak air yang terpisah. Emulsi santan terdiri dari $20-35 \%$ minyak, $55-75 \%$ air dan 5-10\% protein (Tansakul dan Chaisawang, 2005).

Jumlah persentasi starter ragi tape yang ditambahkan berturut-turut $10 \%$, 20\% dan $30 \%$ pada krim dengan rasio kelapa parut terhadap air yang sama cenderung meningkat kadar air. Hal ini karena makin banyak jumlah starter ragi tape yang ditambahkan maka kadar air minyak kelapa murni juga semakin banyak karena starter ragi tape akan terakumulasi dengan kadar air minyak kelapa murni yang dihasilkan, sehingga terjadi kenaikan kadar air akibat penambahan starter ragi tape.

$$
\text { Air dalam bahan makanan }
$$

terdapat dalam berbagai bentuk diantaranya adalah air terikat secara lemah, air terabsorbsi (terserap) pada permukaan makromolekuler seperti protein, pectin, pati, sellulosa, dsb (Slamet Sudarmadji, 1989). Disamping itu menurut Ketaren (1986), keberadaan air dalam minyak dapat merusak kualitas akibat reaksi hidrolisa.

\section{Asam Lemak Bebas.}

Penambahan persentasi starter ragi tape pada pengolahan minyak kelapa murni dengan jumlah yang bervariasi berturut-turut $10 \%, 20 \%$ dan $30 \%$ ternyata berpengaruh nyata terhadap kadar asam lemak bebas pada minyak kelapa murni yang diperoleh, seperti disajikan pada tabel 2.

Tabel 2. Kadar asam lemak bebas pengolahan minyak kelapa penambahan starter ragi tape.

\begin{tabular}{|l|l|}
\hline Perlakuan & Asam Lemak Bebas Minyak Kelapa Murni (\%) \\
\hline $\mathrm{A}_{3}$ & $0.5133 \mathrm{a}$ \\
$\mathrm{A}_{2}$ & $0.4133 \mathrm{~b}$ \\
$\mathrm{~A}_{1}$ & $0.3167 \mathrm{c}$ \\
\hline
\end{tabular}

Keterangan : Angka-angka pada jalur yang sama diikuti oleh huruf kecil yang sama menunjukkan berbeda nyata menurut Uji Lanjut DMRT pada taraf 5\%.

Dari tabel di atas kadar asam lemak bebas tertinggi diperoleh pada penambahan ragi tape $30 \%$ sedangkan kadar air terendah adalah pada penambahan ragi tape $10 \%$ yaitu $\mathrm{A}_{1}$ $(10 \%)=0,01 \%, \mathrm{~A}_{2}(20 \%)=0,02 \%$, dan $\mathrm{A}_{3}(30 \%)=0,03 \%$. Semakin banyak jumlah stater ragi yang ditambahkan maka semakin banyak juga asam lemak bebas. Asam lemak bebas ditimbulkan karena reaksi hidrolisa atau oksidasi. Asam lemak bebas dapat terbentuk oleh reaksi hidrolisa yang dipercepat oleh air dalam bahan. Rindit Pambayun (2004) menyebutkan bahwa penggunaan asam dalam proses pengolahan minyak kelapa murni dapat menghasilkan asam lemak bebas yang tinggi. Sumitro Djanun (2006) menyatakan pada pembuatan minyak kelapa murni rasio kelapa parut terhadap air dalam jumlah minyak pancing yang sama akan cenderung mempengaruhi kadar asam lemak bebas.

Asam lemak bebas merupakan salah satu indikator yang menentukan kualitas minyak terutama dikorelasikan 
dengan tingkat kerusakan minyak yang dapat ditimbulkan oleh reaksi hidrolisa dan oksidasi. Al-Kahtani (1991) menyatakan bahwa terbentuknya asam lemak bebas oleh reaksi kimia hidrolisa dipercepat oleh keberadaan air dalam bahan.

\section{Rendemen Virgin Coconut Oil.}

Tabel 3. Rendemen minyak kelapa murni dengan penambahan stater ragi tape

\begin{tabular}{|l|l|}
\hline Perlakuan & Rendemen Minyak Kelapa Murni (\%) \\
\hline A3 & $24.25 \mathrm{a}$ \\
A2 & $23.88 \mathrm{~b}$ \\
A1 & $23.82 \mathrm{c}$ \\
\hline
\end{tabular}

Keterangan : Angka-angka pada jalur yang sama diikuti oleh huruf kecil yang sama menunjukkan berbeda nyata menurut Uji Lanjut DMRT pada taraf 5\%.

Dari tabel di atas hasil rendemen yang didapatkan cenderung meningkatkan rendemen terdapat perbedaan yang nyata $(\mathrm{p} \leq 0,05)$ antara penambahan $\mathrm{A}_{1}(10 \%)=$ $23,83 \%, \mathrm{~A}_{2}(20 \%)=23,88 \%$, dan $\mathrm{A}_{3}$ $(30 \%)=24,25 \%$. Rendemen tertinggi diperoleh pada penambahan ragi tape $30 \%$ sedangkan rendemen terendah adalah pada penambahan ragi tape $10 \%$. Jadi ini menunjukkan bahwa adanya perbedaan rendemen pada masingmasing perlakuan. Semakin tinggi konsentrasi ragi tape pada pembutan minyak kelapa murni maka semakin tinggi pula rendemen yang didapat.

Dengan penambahan ragi tape, globula minyak dalam santan ditarik oleh ragi tape yang ditambahkan sampai akhirnya minyak mengalami koalsensi secara sempurna. Tarikan ini akan mengubah air dan protein yang sebelumnya terikat dalam santan menjadi terputus dan tidak stabil, sehingga dengan penambahan minyak pancing yang kemudian diaduk sampai semua minyak pancing terdistribusi secara homogen dapat mengintervensi sistem emulsi sehingga berdampak pada penyatuan/penggabungan massa minyak (Sukartin dkk, 2005).

\section{KESIMPULAN DAN SARAN}

\section{Kesimpulan}

Dari hasil penelitian pengolahan minyak kelapa murni (Virgin Coconut Oil) terhadap parameter yang diamati dapat diambil kesimpulan sebagai berikut:

1. Persentase ragi tape memberikan pengaruh yang sangat nyata terhadap rendemen hasil, kadar air, asam lemak bebas/FFA, organoleptik aroma, dan organoleptik warna.

2. Semakin banyak penambahan ragi tape pada pengolahan minyak kelapa murni maka kualitas mutu minyak kelapa yan dihasilkan semakin tidak bagus tapi sebaliknya rendemen hasil meningkat.

3. Untuk kualitas yang terbaik pada minyak kelapa murni dengan penambahan stater ragi tape $A_{1}(10 \%)$ yaitu dengan kadar air $\mathrm{A}_{1}(10 \%)=$ $0,11 \%$, asam lemak bebas $\mathrm{A}_{2}(20 \%)$ $=0,02 \%$, rendemen hasil $\mathrm{A}_{2}(20 \%)=$ $23,88 \%$, organoleptik aroma $\mathrm{A}_{2}$ 
$(20 \%)=3,00$, dan organoleptik warna $\mathrm{A}_{2}(20 \%)=3,00 \%$.

\section{Saran}

Perlu pengkajian mendalam terhadap waktu pengolahan dan juga pemisahan minyak setelah penambahan minyak pancing serta teknik pengadukan yang optimum yang dapat merusak penstabil emulsi. Untuk pengolahan VCO dengan bantuan ragi tape disarankan menggunakan starter $20 \%$ agar diperoleh rendemen tinggi dan mutu VCO memenuhi standar.

\section{DAFTAR PUSTAKA}

Al-Kahtani,H,A. 1991. Survey of Quality of Used Frying Oils from Restaurant. JOOCS 68 (11): 857862

Andi Nur Alamsyah. 2005. Virgin Coconut Oil. Minyak Penakluk Penyakit. PT.Agro Media Pustaka. Jakarta.

Anonim. 2002. Statistik Indonesia. Biro Pusat Statistik Jakarta.

Anshori. 1985. Pengantar Teknologi Fermentasi. Dipdikbud Dirjen Perguruan Tinggi PAU Pangan dan Gizi. IPB. Bogor.

Asian and Pacifik Coconot Commnity (APCC). 2004. Coconut Statistical Year Book. Kuningan, Jakarta. $291 \mathrm{hlm}$.

Apriyanto, M. 2007. Recorvery Protein Blondo Sebagai Hasil Samping Pengolahan VCO. Tesis S-2 Sekolah Pascasarjana Universitas Gadjah Mada. Yogyakarta.

Board of Riau Province. 2005. Profil of infesment Project Riau Province. Hlm 97-104.

Buckle, Edward, dan Fleed, Watton. 1988. Ilmu Pangan. UI Press. Jakarta.
Desrosier, N.W. 1987. Teknologi Pengawetan Pangan. UI Press. Jakarta.

Dwijoseputro. 1990. Dasar-Dasar Mikrobiologi. Djambatan. Malang.

Ketaren, S. 1986. Pengantar teknolgi minyak dan lemak pangan. Penerbit Universitas Indonesia. Jakarta.

Rindengan. 2003. Pengolahan Minyak Kelapa Murni (Virgin Coconut Oil) untuk Industri Farmasi dan Kosmetik Makalah disampaikan pada Aplikasi Teknologi Pasca Panen Komoditas Perkebunan. Makasar.

Sudarmadji, S., Haryono, B. dan Suhardi. 1997. Prosedur Analisa Bahan Makanan dan Petanian. Liberty. Yogyakarta.

Suhardiyono, L. 1988. Tanaman Kelapa. Kanisius. Yogyakarta.

Sukartono, Kuncoro J. dan Sitangguri Maloedyn. 2005. Gempur Penyakit dengan VCO. PT. Agro Media Pustaka. Jakarta.

Sumitro. 2006. Teknologi pembuatan minyak kelapa dengan tanpa pemanasan. Tesis S-2 Sekolah Pascasarjana Universitas Gadjah Mada. Yogyakarta.

Tansakul, A. and P., Chaisawang. 2005. Thermophysical properties of coconut milk. Journal of Food Engineering 73: 276-280.

Tarigan. 1988. Pengantar Mikrobiologi. Departemen Pendidikan dan Kebudayaan Direktorat Jendral Perguruan Tinggi. Jakarta.

Winarno. 1994. Pengantar Teknologi Pangan. Gramedia Pustaka Utama. Jakarta. 